OPEN ACCESS

Edited by:

Wencang Zhou,

Montclair State University,

United States

Reviewed by:

Ning Chen,

University of Canterbury, New Zealand

Kangkang Yu,

Renmin University of China, China

*Correspondence:

Heqi Jia

mohejiaheqi@sina.com

Specialty section:

This article was submitted to

Organizational Psychology,

a section of the journal

Frontiers in Psychology

Received: 27 November 2021 Accepted: 16 December 2021

Published: 14 January 2022

Citation:

$X u Z$ and Jia H (2022) The Influence of COVID-19 on Entrepreneur's

Psychological Well-Being.

Front. Psychol. 12:823542.

doi: 10.3389/fpsyg.2021.823542

\section{The Influence of COVID-19 on Entrepreneur's Psychological Well-Being}

\author{
Zhengda $X u^{1}$ and Heqi Jia ${ }^{2 *}$ \\ ${ }^{1}$ Business School, Beijing Technology and Business University, Beijing, China, ${ }^{2}$ Business School, Central University of \\ Finance and Economics, Beijing, China
}

This research focuses on the influence of COVID-19 on entrepreneurs' psychological well-being (PWB) in China. A start-up's performance is believed to play an important moderating role. This study uses 2 years of tracking data of 303 entrepreneurs from Shandong Providence, China. Based on conservation of resources (COR) theory, this study found that COVID-19 will significantly decrease entrepreneurs' PWB. A start-up's past performance will enhance the negative influence of COVID-19 on entrepreneurs' PWB. This study contributes to the literature on entrepreneurship, COR, and PWB. The findings can also guide entrepreneurs to maintain well-being during the pandemic and post-pandemic era.

Keywords: COVID-19, entrepreneur, psychological well-being, firm performance, COR theory

\section{INTRODUCTION}

The COVID-19 pandemic is not only negatively affecting the economic growth (Walmsley et al., 2020; Backer et al., 2021; Elgin et al., 2021), and business management (Andries et al., 2020; Fairlie and Fossen, 2021; Spiegel and Tookes, 2021; Verbeke and Yuan, 2021), but it is also influencing peoples' physical health (Shamim et al., 2021) and well-being (Khan et al., 2020; Ripp et al., 2020). The SMEs have suffered more from the pandemic than big companies. Based on Coronavirus (COVID-19): SME Policy Responses, published by the Organization for Economic Co-operation and Development, as of May 2020,99.1\% of China’s big companies had resumed normal operations, whereas only $91 \%$ of small and medium-sized enterprises (SMEs) had resumed normal operations. Compared with large enterprises, SMEs had shown a weaker ability to recover (OECD, 2020).

Entrepreneurs suffer from the double impact of the pandemic. Their health is threatened by the pandemic directly. Their income decreases as their start-up firms are closed, which will further affect their well-being. According to the Enterprise Survey for Innovation and Entrepreneurship in China, entrepreneurs showed a high level of anxiety during the pandemic. For example, Rong Chao, founder of Yihua Technology (a fresh flower B2B platform company), said that Spring Festival and Valentine's Day were generally the peak seasons for the fresh flower industry, but the outbreak of the pandemic made the company lose income, which made him feel stressed and lose sleep (Peng, 2020). The vice president of Northern Light Venture Capital stated in an interview that if the companies performed and financed well before the pandemic, it would be harder for them to survive than for those with poor performance during the pandemic which made entrepreneurs stressed out (Wang, 2020). In this context, how entrepreneurs maintain well-being has become a very important topic (Patel and Rietveld, 2020). 
Entrepreneurs' psychological well-being (PWB) has increasingly attracted scholars' interests (Marshall et al., 2020). Currently, researchers have already found that entrepreneurs' PWB can help them recognize opportunities (Gielnik et al., 2012) and help their firms perform better (Chao et al., 2007; Baron, 2008; Uy et al., 2017). Many studies have already analyzed the factors that affect entrepreneurs' PWB, such as entrepreneurs' prior start-up experience, active coping, moods, and motivations (Uy et al., 2013, 2017; Hahn, 2020). However, few studies have focused on entrepreneurs' PWB during the COVID-19 pandemic and the moderating role of firms' characteristics. While the organization and environment characteristics will also affect the entrepreneur's well-being.

Scholars have found people chose different coping strategies when facing difficulties under different context (Moos, 1984; Hobfoll, 2001; Uy et al., 2013). The entrepreneur's behavior would be adjusted according to the enterprise s' characteristics. Entrepreneurs are more inclined to make risky decisions in smaller enterprises, while entrepreneurs are less inclined to make risky decisions in larger enterprises (Smith et al., 1988). However, no research has focused on how the interactive effect of environmental changes and firm characteristics influence entrepreneurs' well-being.

Moreover, current research on the relationship between the pandemic and individual PWB has been relatively limited, and the impact of the pandemic on entrepreneurs' well-being particularly has been overlooked. For entrepreneurs from the same area, the pandemic will have different impact on them. Based on the prior research, we think this may be caused by their start-up's characteristics. However, the relevant impact mechanism has not been paid attention to.

Using conservation of resources (COR) theory, this paper explains how the pandemic and the characteristics of entrepreneurial companies will affect entrepreneurs' PWB. COR theory explains why people strive to obtain, retain and protect resources, and how individuals respond to threats of losing resources (Hobfoll, 1989). This theory has been used by many scholars in entrepreneurship area to predict stress response of the resource losing situation (Bonanno et al., 2007; Lanivich, 2015; Williams and Shepherd, 2016). This paper uses the data of a 2-year follow-up survey of entrepreneurs in Shandong Province, China; analyzes the impact of the severity of the pandemic in the region where the SMEs are located on the entrepreneur's PWB; and estimates the moderating effect of firm performance. This paper finds that the pandemic will significantly decrease the PWB of entrepreneurs, and firm performance strengthen the negative relationship between the pandemic and entrepreneurs' PWB.

This paper makes the following contributes. First, according to COR theory, this paper explores how resource direct loss, potential loss, and difficulty in obtaining new resources for startups during the pandemic decrease entrepreneurs' PWB. This enriches the existing PWB research framework. Second, this paper incorporates the organizational context into the framework of research on entrepreneurial wellbeing. This paper creatively analyzes how the characteristics of firms affect the relationship between the pandemic and entrepreneurs' well-being, which provides a new perspective for further understanding the relationship between entrepreneurs and firms. Finally, this paper makes some contributions to the COR theory. Using the samples from entrepreneurial context, this paper extending the boundary of COR theory by extending the scope of the resources list proposed by Hobfoll (2011). The research conclusion of this paper also helps entrepreneurs better understand the past and future expected performance of firms in the pandemic and postpandemic eras. It also helps them maintain PWB and enables enterprises to achieve sustainable development.

\section{THEORY AND HYPOTHESIS}

\section{Conservation of Resource Theory}

COR theory proposes that when an individual perceives that resources are threatened by loss, experiences the actual loss of resources, or does not obtain enough resources after making an appropriate investment in them, they will experience stress and decreased well-being (Hobfoll, 1989, 2001). The core concept of COR theory is resource. Hobfoll (1989) defined resources as valuable objects, personal characteristics, conditions, energies, or anything that can help a person gain more of the above mentioned resources. In developing of the theory, scholars have expanded the definition of resources to include anything that can help people achieve their goals (Halbesleben et al., 2014). The COR theory explains that environmental factor is an important factor threaten resource loss (Hobfoll, 1989). Environmental challenges the instrumental value and symbolic value of resources that can help people to gain more resources and define people who they are (Brown and Andrews, 1986). The dynamic and uncertain nature of the environment is the main reason that cause resource uncertainty (Adomako, 2021).

The COR theory has been widely used in many research situations, such as organizational situations, and health situations (Hobfoll, 2001). For example, some scholars used COR theory to explain how individual human capital can bring positive emotions to themselves through entrepreneurship in disaster situations (Williams and Shepherd, 2016). Scholars also used COR theory to explain entrepreneurial behavior (Lanivich, 2015) and the consequences of entrepreneurial failure ( $\mathrm{Yu}$ et al., 2020). COR theory combines a variety of perspectives to explain the relationship between entrepreneurship and well-being, such as the value creation perspective (Brieger et al., 2021) and work-family balance perspective (Leung et al., 2020). Acquiring, protecting, and developing resources are important mechanisms in COR theory to deal with resource loss, which explains why some people can deal with resource uncertainty (Lanivich, 2015; Adomako, 2021). This theory can also help us understand how the loss of resources affects people's mental health (Hobfoll, 1989; Lanivich, 2015). Isolation, shutdown, and other activities during the pandemic greatly affect the preservation and acquisition of enterprise resources. Therefore, we can explore the internal mechanism of the impact of the pandemic on entrepreneurs' PWB using COR theory.

\section{COVID-19 and Entrepreneur's PWB}

According to COR theory, personal psychological stress will occur when their resources are threatened with loss, their 
resources are actually lost, or they fail to gain sufficient resources following significant resource investment (Hobfoll, 2001). Moreover, the occurrence of negative life events often has a stronger impact on individual physiology, cognition, emotion, and social response than positive life events (Hobfoll, 2001). Entrepreneurs are more sensitive to resource loss than non-entrepreneurs (Lanivich, 2015). The entrepreneurship is a process for an entrepreneur recognizing, developing and managing resources (Corbett, 2005; Busenitz and Arthurs, 2007). The entrepreneurs' self-value is generated from entrepreneurial process (Williams and Shepherd, 2016). According to the COR theory, the broad definition of resources is anything that can help people achieve their goals (Halbesleben et al., 2014). Entrepreneurs incline to pay attention to the resources that are related to the start-ups. The resource changes will influence entrepreneurs' behavior. Scholars found that entrepreneur persistence will decrease with the potential resource loss (Holland and Shepherd, 2013).

The COVID-19 pandemic, a negative event of a wide scope and long duration, will have a strong impact on individuals (Wolfe and Patel, 2021). The pandemic is a typical resource-poor environment (Thorgren and Williams, 2020). Thus, we conduct that there are two possible mechanisms for the impact of the pandemic on entrepreneurs' PWB.

On the one hand, the pandemic has brought direct and potential losses of resources. The COVID-19 pandemic rapidly led the world to an unexpected recession (World Bank, 2020). To slow down the spread of COVID-19, many governments have

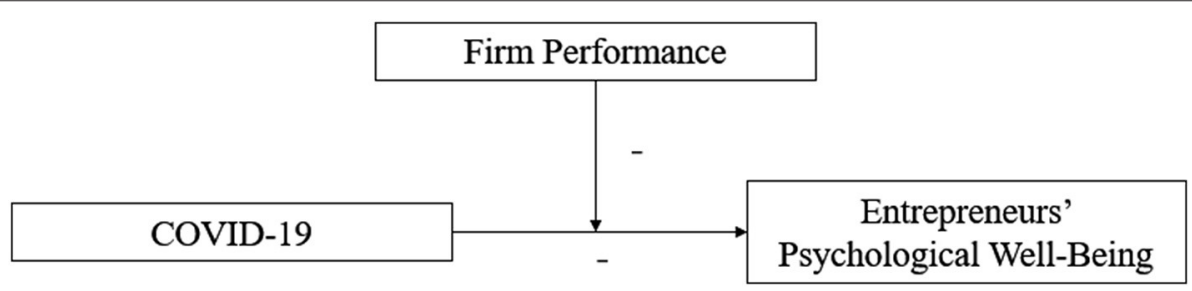

FIGURE 1 | Theoretical model.

TABLE 1 | Measurement items and reliabilities.

\begin{tabular}{|c|c|c|c|c|c|c|c|c|}
\hline Variables & Items & Alpha & CMIN/DF & CFI & GFI & RMSEA & AVE & CR \\
\hline \multirow[t]{12}{*}{ Psychological well-being } & Have you been feeling not perfectly well or not in good health? & 0.756 & 3.573 & 0.924 & 0.921 & 0.092 & 0.905 & 0.445 \\
\hline & Been felling run down and out of sorts? & & & & & & & \\
\hline & Have you felt that you are ill? & & & & & & & \\
\hline & Felt constantly under strain? & & & & & & & \\
\hline & Been getting edgy and bad-tempered? & & & & & & & \\
\hline & Been getting scared or panicky for no good reason? & & & & & & & \\
\hline & Felt that you are playing a useful part in things? & & & & & & & \\
\hline & Felt capable of making decisions about things? & & & & & & & \\
\hline & Felt on the whole you are doing things well? & & & & & & & \\
\hline & Been thinking of yourself as a worthless person? & & & & & & & \\
\hline & Felt that life is entirely hopeless? & & & & & & & \\
\hline & Felt that life isn't worth living? & & & & & & & \\
\hline \multirow[t]{7}{*}{ Firm performance(in 2019) } & Sales growth & 0.903 & 1.412 & 0.995 & 0.983 & 0.037 & 0.825 & 0.402 \\
\hline & Market share growth & & & & & & & \\
\hline & Net profit margin & & & & & & & \\
\hline & Return on equity & & & & & & & \\
\hline & Return on assets & & & & & & & \\
\hline & Return on sales & & & & & & & \\
\hline & Profit growth & & & & & & & \\
\hline \multirow[t]{7}{*}{ Firm performance(in 2020) } & Sales growth & 0.905 & 2.402 & 0.983 & 0.969 & 0.068 & 0.831 & 0.416 \\
\hline & Market share growth & & & & & & & \\
\hline & Net profit margin & & & & & & & \\
\hline & Return on equity & & & & & & & \\
\hline & Return on assets & & & & & & & \\
\hline & Return on sales & & & & & & & \\
\hline & Profit growth & & & & & & & \\
\hline
\end{tabular}


TABLE 2 | Mean, standard deviation, and correlation of study variable.



$N=303 .{ }^{\star \star} p<0.01 .{ }^{\star}<0.05$

taken drastic measures, such as closing borders, sealing up cities, and promulgating stay-at-home restrictions and social distancing policies (Kuckertz et al., 2020; Han et al., 2021; Tang et al., 2021). These policies prevent the process of resources development. The market demand had decreased significantly because consumers were unable to shop in the stores (Fairlie and Fossen, 2021), this caused the direct loss of the resource of the firm. The fixed cost still exists after the shutdown of enterprises, but firms are unable to produce and obtain profits, which has had a serious impact on global entrepreneurial activities (Björklund et al., 2020; Brown and Rocha, 2020; Patel and Rietveld, 2020). These challenges hinder entrepreneurs from achieving their goals. According to the COR theory, entrepreneurs will regard these as the loss or potential loss of resources, so their PWB will be reduced.

The pandemic has reduced the value that human capital can provide (Yarovaya et al., 2021), making it difficult for enterprises to respond and adjust effectively to emergencies. Human resource is one of the most important resources for start-ups. It is also the carrier of the knowledge resource (Halbesleben et al., 2014). The loss of human resource not only influence the operation of the firms directly but also influence the ability and efficacy for start-ups to obtain and explore new resource (Williams and Shepherd, 2016). The pandemic led to the inability of some employees to work on duty, and the low efficiency of remote work decreased the performance of employees (Kumar et al., 2021; Wang et al., 2021). These factors have further reduced the income of enterprises. The decrease of enterprise income will lead to a series of layoffs, which will further reduce the human resources of the enterprise (Butterick and Charlwood, 2021). Even if the pandemic has been temporarily controlled in some areas, the possibility of recurrence will also bring potential losses to enterprises. Once the pandemic reappears, enterprises will face shutdown again. Therefore, in areas with serious pandemic recurrence, SMEs face greater potential resource losses. According to the COR theory, direct loss and potential loss of resources will reduce the well-being of entrepreneurs. Therefore, the more serious the pandemic, the more resource losses of the firm, the lower the PWB of entrepreneurs.

On the other hand, the pandemic has increased the difficulty of obtaining new resources, making entrepreneurs unable to obtain sufficient resources even they make a great effort. Scholars have found that the pandemic has significantly reduced the total capital in the Chinese market, increased the scarcity of market resources, and made it difficult for entrepreneurs to obtain investment by making the effort (Brown and Rocha, 2020). The pandemic also causes entrepreneurs to make efforts 
more difficult. During the pandemic period, many countries have promulgated stay-at-home restrictions (Kuckertz et al., 2020; Tang et al., 2021), which has made it impossible for entrepreneurs to take the initiative to find and obtain resources. The pandemic has also reduced the trust behavior of the overall market (Li et al., 2021) and has increased the cost of resource acquisition. According to the COR theory, entrepreneurs' wellbeing will decrease when they cannot obtain resources through effort. The more serious the pandemic becomes, the less likely entrepreneurs will be to obtain new resources, and the lower will be the PWB of entrepreneurs. Based on this, we proposed the following hypothesis:

H1: Covid-19 pandemic will decrease entrepreneurs' PWB.

\section{The Moderating Effects of Firm Performance on the Influence of Pandemic on PWB}

The performance of start-ups will affect the relationship between the pandemic and entrepreneurs' PWB. An enterprise's performance is closely related to its resources (Bharadwaj, 2000; Beleska-Spasova et al., 2012). According to resource-based view $(\mathrm{RBV})$, resources are necessary for the operation of enterprises (Alvarez and Busenitz, 2007). If an enterprise wants to perform well, it must acquire a large amount of resource investment, such as human resources (Hitt et al., 2001), technical resources (Powers and McDougall, 2005), or all kinds of capital (Quas et al., 2021). Based on RBV and COR theory, there may be two mechanisms for the impact of the performance of SMEs on the relationship between the pandemic and entrepreneurs' PWB.

First, the good past performance of firms will increase entrepreneurs' expectations of available resources in the future. Managers will infer the future performance of firms based on their past performance and make corresponding decisions (Lages et al., 2008, 2013; Hadad et al., 2013). Therefore, when the past performance of SMEs is good, entrepreneurs will expect to obtain more benefits and resources in the future. During the pandemic, the governments issued many shutdown policies, and enterprises were unable to continuously obtain resources from outside (Brown and Rocha, 2020), which makes it difficult to realize the business expectations of entrepreneurs. The better the past performance, the bigger the gap between entrepreneurs' expectations and reality. According to COR theory, entrepreneurs show lower PWB when they perceive greater potential resources loss. On the contrary, if the previous performance is poor, the entrepreneurs' expectations for the future growth of the enterprise is relatively low. The potential future loss perceived by entrepreneurs during the pandemic is also low. Therefore, the negative impact of the pandemic on entrepreneurs' PWB is weaker when the past performance is bad.

Second, when the past performance of the firm is good, the pandemic will cause more resource loss directly. Thus, the good past performance increases the negative impact of the pandemic on entrepreneurs' PWB. According to RBV, good performance means that the SMEs had invested more resources in the early stage (Mishra and Zachary, 2013; Choi et al., 2021), and the SMEs had accumulated more resources at present. To ensure the sustainable competitive advantage and exploit the potential opportunities in the future, enterprises with good performance will continue to invest more resources to ensure a good growth rate (Phillips and Kirchhoff, 1989), such as continuously looking for venture capital (Chittenden et al., 1996). When the pandemic occurs, no matter how much the resource of start-ups has invested before, the expected income they can obtain will be reduced to a very low level. This makes the enterprises with better performance face greater losses, so the PWB of entrepreneurs will be worse.

Based on these analyses, this paper puts forward the following hypothesis:

H2: Firm performance will moderate the relationship between the COVID-19 pandemic and entrepreneurs' PWB. Specifically,

TABLE 3 | Results of regression analysis.

\begin{tabular}{|c|c|c|c|}
\hline & \multicolumn{3}{|c|}{ PWB } \\
\hline & Model 1 & Model 2 & Model 3 \\
\hline \multirow[t]{2}{*}{ Gender } & $0.100^{\dagger}$ & 0.088 & 0.076 \\
\hline & (1.672) & (1.560) & (1.392) \\
\hline \multirow[t]{2}{*}{ Age } & $-0.015^{\star \star}$ & $-0.015^{\star \star}$ & $-0.013^{\star \star}$ \\
\hline & $(-2.999)$ & $(-3.261)$ & $(-2.933)$ \\
\hline \multirow[t]{2}{*}{ Education } & 0.035 & 0.046 & $0.061^{\dagger}$ \\
\hline & $(0.952)$ & $(1.327)$ & $(1.778)$ \\
\hline \multirow[t]{2}{*}{ Marriage } & $0.222^{*}$ & 0.023 & 0.033 \\
\hline & $(2.177)$ & $(0.222)$ & $(0.329)$ \\
\hline \multirow[t]{2}{*}{ Experience } & $-0.111^{\star \star}$ & $-0.100^{\star \star}$ & $-0.095^{\star \star}$ \\
\hline & $(-3.183)$ & $(-3.040)$ & $(-2.972)$ \\
\hline \multirow[t]{2}{*}{ Firm age } & 0.037 & $0.047^{\star}$ & $0.046^{*}$ \\
\hline & $(1.505)$ & (2.034) & (2.036) \\
\hline \multirow[t]{2}{*}{ Firm size } & -0.034 & -0.035 & $-0.050^{\dagger}$ \\
\hline & $(-1.130)$ & $(-1.224)$ & $(-1.761)$ \\
\hline \multirow[t]{2}{*}{ Ind1 } & -0.084 & -0.075 & -0.029 \\
\hline & $(-1.079)$ & $(-1.025)$ & $(-0.405)$ \\
\hline \multirow[t]{2}{*}{ Ind2 } & $-0.159^{\star}$ & -0.118 & -0.090 \\
\hline & $(-2.095)$ & $(-1.647)$ & $(-1.287)$ \\
\hline \multirow[t]{2}{*}{ Ind3 } & $-0.264^{\star \star}$ & $-0.220^{\star \star}$ & $-0.175^{\star}$ \\
\hline & $(-3.000)$ & $(-2.648)$ & $(-2.156)$ \\
\hline \multirow[t]{2}{*}{ COVID-19 } & & $-0.002^{\star \star \star}$ & $-0.002^{\star \star \star}$ \\
\hline & & $(-5.012)$ & $(-5.471)$ \\
\hline \multirow[t]{2}{*}{ Firm performance } & & $0.386^{\star \star}$ & $0.373^{\star \star}$ \\
\hline & & $(-3.106)$ & $(3.088)$ \\
\hline \multirow[t]{2}{*}{ COVID-19 * firm performance } & & & $-0.006^{\star \star \star}$ \\
\hline & & & $(-4.345)$ \\
\hline \multirow[t]{2}{*}{ Constant } & $4.318^{\star \star \star}$ & $4.444^{\star \star \star}$ & $4.457^{\star \star \star}$ \\
\hline & (10.769) & (11.779) & (12.171) \\
\hline$R^{2}$ & 0.144 & 0.253 & 0.299 \\
\hline$\Delta \mathrm{R}^{2}$ & 0.144 & 0.109 & 0.046 \\
\hline F-Statistic & $4.907^{\star \star \star}$ & $8.188^{\star \star \star}$ & $9.477^{\star \star \star}$ \\
\hline
\end{tabular}

$N=303 .{ }^{\dagger} p<0.1,{ }^{*} p<0.05,{ }^{* *} p<0.01,{ }^{* * *} p<0.001$.

Numbers in brackets refer to $t$-value. 
the better the performance of the firm, the greater the negative impact of the pandemic on the entrepreneurs' PWB.

This study summarizes the hypotheses of the present study in Figure 1.

\section{METHODS}

\section{Sample}

This study conducted a two-wave survey by questionnaire to verify the hypotheses. This study selects only one province for collecting data to reduce the impact of macro-environmental factors, such as different entrepreneurial policies, regional epidemic severity, and policy differences during the epidemic that affect entrepreneurs. According to the Statistical Yearbook of the National Bureau of Statistics of China in 2020, Shandong province ranked the first in China in terms of the number of self-employed by the end of 2019. Shandong province is one of the most active entrepreneurial areas in China. Therefore, it is appropriate to use the SMEs in Shandong province for the sample of this study.

This study first collected the data in November 2019. In the first survey, we obtained 305 founder-CEOs' basic information (e.g. gender, age, education, marriage, and entrepreneurial experience). We also asked the entrepreneur to introduce one top management team member to finish another questionnaire to avoid the common method bias (Chin et al., 2021). This study collected basic firm information from this manager (e.g., firm age, firm size, firm performance, and industry). In March 2020, we tracked these founder-CEOs and managers to collect the dependent variable and moderate variable. We obtained 303 valid samples in 2020. Thus, the final sample in this study is 303 .

Among these 303 business owners, there are 215 male entrepreneurs (70.96\%) and 88 female entrepreneurs (29.04\%). The age of entrepreneurs is concentrated between 31 and 40 years old, with the largest proportion at $54.1 \%$. As for the educational background, most of the entrepreneurs graduated from high school or technical high school (34.32\%) and junior college (35.97\%). In addition, 276 entrepreneurs are married, and 202 entrepreneurs have prior start-up experience.

Among these 303 start-ups, the most of them were established within 3 years $(97.36 \%)$. The assist size of the start-ups was under 1 million RMB (90.42\%). In addition, there are 74 start-ups in wholesale and retail industry $(24.42 \%), 68$ start-ups in resident services and other services industry (22.44\%), and 55 start-ups in accommodation and catering industry (18.15\%).

\section{Measurement}

This study presents the measurement items for psychological well-being and firm performance in Table 1.

\section{COVID-19}

This study used the number of confirmed cases of the coronavirus in the city where a given company is located to measure the impact of COVID-19. The greater the number of confirmed cases, the larger the impact of the pandemic. This study used the real-time statistic of the pandemic on Sina News (one of the largest news websites in China) to collect the cumulative number of confirmed cases in the city where a given company is located before March 1, 2020. ${ }^{1}$ The spread of the coronavirus has been effectively controlled in China since the end of February 2020. The number of confirmed cases has rarely increased since March 1 st, 2020.

\section{Psychological Well-Being}

This study used the General Health Questionnaire developed by Goldberg and Hillier (1979) to measure entrepreneurs' PWB. This measurement has been widely used in entrepreneurship studies (Uy et al., 2013, 2017; Hahn, 2020; Marshall et al., 2020). Participants were required to respond to questions based on the situation in the past few weeks. This scale includes 12 items, such as the following: "Have you been feeling not perfectly well or not in good health?" "Have you felt constantly under strain?" The participants answered on a 4-point scale, with 1 standing for "not at all, and 4 standing for "much more than usual." The Cronbach's alpha value is 0.756 , which means the reliability is acceptable. In addition, the results $(\mathrm{CMIN} / \mathrm{DF}=3.573, \mathrm{CFI}=0.924$, GFI $=$ 0.921 , RMSEA $=0.092$ ) of the confirmatory factor analysis prove that the validity is acceptable.

\section{Firm Performance}

This study used the firm performance growth rate to measure firm performance (Zhao et al., 2010). Using growth rate can avoid the performance biases caused by firm size and firm industry. We used the multidimensional construct of performance in 2020 minus the multidimensional construct of performance in 2019, then we divide the multidimensional construct of performance in 2019 to calculate the firm growth rate. The larger the value, the better the firm performance.

The multidimensional construct of firm performance was measured by a 7-item scale (Stam et al., 2014; Rauch and Hatak, 2016; e.g., sales growth, market share growth). In 2019, we asked the manager, "How is the competition status for your company compared with a major competitor in the same industry?" The participants answered on a 5-point scale, with 1 standing for "falling far behind" and 5 standing for "stronger than competitors." The Cronbach's alpha value is 0.903 , which means the reliability is acceptable. In addition, the results (CMIN/DF $=1.412$, CFI $=0.995$, GFI $=0.983$, RMSEA $=0.037$ ) of the confirmatory factor analysis prove that the validity is acceptable.

The measurement of firm performance in 2020 is the same as the in 2019. The alpha reliability of the performance in 2020 is 0.905 , which means the reliability is acceptable. In addition, the results $(\mathrm{CMIN} / \mathrm{DF}=2.402, \mathrm{CFI}=0.983, \mathrm{GFI}=0.969, \mathrm{RMSEA}=$ 0.068 ) of the confirmatory factor analysis prove that the validity is acceptable.

\section{Controls}

Following the previous research, this study controls some individual-level and firm-level variables that can affect entrepreneurs' PWB (Uy et al., 2013, 2017; Hahn, 2020).

At the individual level, this study controlled for entrepreneurs' gender $(1=$ "male" and $0=$ "female"), age, and education ${ }^{1}$ Data source: https://news.sina.cn/project/fy2020/yq_province.shtml?city=
CN37010000000000. 
( 1 = "primary school," $2=$ "secondary school," $3=$ "high school/technical high school" 4 = "junior college," 5 = "bachelor," $6=$ "master," 7 = "doctoral"). Marriage status was measured by a dummy variable. We coded 1 for "married" and 0 for "unmarried or divorced". The entrepreneurial experience was measured by whether the entrepreneurs had established a firm before the current business.

At the firm level, this study controlled for the firm age, firm size, and firm industry. We asked the manager about which year the company was established. Then, we used 2020 minus the established year to obtain the firm age. Firm size was measured by the natural logarithm of the total firm assets (Tian et al., 2020). This article formed three dummy industrial variables to control, including wholesale and retail (Ind1; $1=$ "Yes" and $0=$ "No"), resident services and other services (Ind2; $1=$ "Yes" and $0=$ "No"), and accommodation and catering (Ind3; $1=$ "Yes" and $0=$ "No").

\section{RESULTS}

\section{Descriptive Statistics and Correlation Analysis}

This study shows the descriptive statistics and correlation coefficients for all variables in Table 2. We see that the correlation coefficient that is higher than 0.1 is significant. The absolute value of the correlation coefficient is $<0.7$, which means there is no multicollinearity. The significant and negative correlation between COVID-19 and PWB $(\mathrm{r}=-0.287, p<0.01)$ indicates that COVID-19 would influence $\mathrm{PWB}$ negatively. The significant and positive correlation between firm performance and PWB $(r=0.255$, $\mathrm{p}<0.01$ ) indicates that firm performance would influence PWB positively.

\section{Regression Analysis}

This study uses hierarchical regression analysis to verify the relationship between COVID-19 and entrepreneurs' PWB, and the moderate effect of firm performance. The results are shown in Table 3. The largest value of the variance inflation factor of all variables is 1.653 , which is lower than 2 and thus indicates that the variables have no multicollinearity problem. The results in Model 2 show that COVID-19 has a significant negative impact on PWB $(\mathrm{b}=-0.002, p=0.000)$. Thus, hypothesis 1 is supported. The results in Model 3 show that the interaction between COVID19 and firm performance has a significant effect on PWB (b $=-0.006, p=0.000$ ). Thus, hypothesis 2 is supported. This study depicted the interaction graph in Figure 2.

\section{Robustness Test}

To ensure the robustness of the model, this study used an alternative moderator variable and dependent variable to rerun the hierarchical regression analysis. The results are shown in Table 4.

This study used the need for recovery to alter PWB. The literature about well-being and recovery are overlapped (Leamy et al., 2011). Need for recovery refers to a mental state in which an individual desperately wants to temporarily recover from job exhaustion. It is a feeling of pursuing quietness for a period (Sonnentag and Zijlstra, 2006; Sonnentag et al., 2010; Kinnunen et al., 2011). Scholars used need for recovery as an indicator of individuals' well-being (Kinnunen et al., 2011; Mache et al., 2020). Thus, we used need for recovery as an alternative variable of PWB. We used a 11-item need for recovery scale adopted from Veldhoven and Broersen (2003; e.g., "I find it difficult to relax at the end of a working day"). The items for this scale are measured on a 5-point scale from 1 ("I do not agree at all") to 5 ("I fully agree"). The higher the score, the higher the entrepreneurs need for recovery. When entrepreneurs need for recovery means they are not in a good psychological wellbeing status. The results in Model 4 show that COVID-19 has a significant positive effect on the need for recovery $(b=0.003$, $p=0.000)$. Thus, hypothesis 1 is supported. The results in Model 5 show that the interaction between COVID-19 and firm performance has a significant effect on the need for recovery $(b$ $=0.003, p=0.042$ ). Thus, hypothesis 2 is supported. The results are robust.

Then, this study used growth in the number of employees as an alternative measurement of the moderator variable. We asked

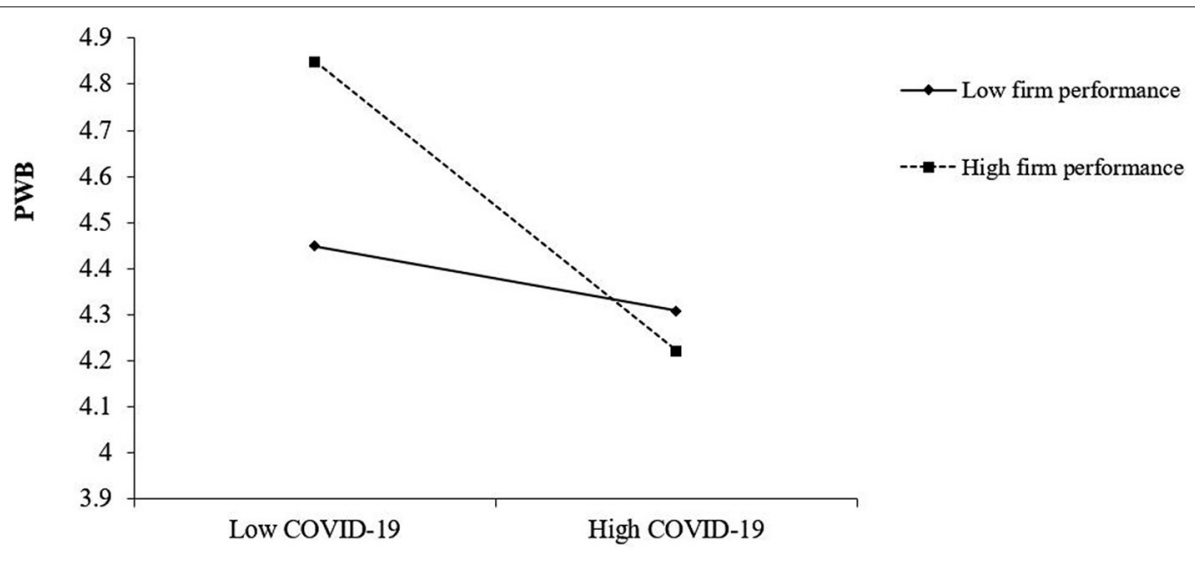

FIGURE 2 | The interaction between COVID-19 and firm performance on PWB. 
TABLE 4 | Regressive results of robustness test.

\begin{tabular}{|c|c|c|c|c|}
\hline & \multicolumn{2}{|c|}{ Need for recovery } & \multicolumn{2}{|c|}{ PWB } \\
\hline & Model4 & Model5 & Model6 & Model7 \\
\hline \multirow[t]{2}{*}{ Gender } & -0.005 & 0.001 & 0.084 & 0.077 \\
\hline & $(-0.080)$ & $(0.02)$ & (1.472) & (1.370) \\
\hline \multirow[t]{2}{*}{ Age } & 0.006 & 0.005 & $-0.017^{\star \star \star}$ & $-0.016^{\star \star}$ \\
\hline & $(1.036)$ & $(0.843)$ & $(-3.600)$ & $(-3.520)$ \\
\hline \multirow[t]{2}{*}{ Education } & 0.000 & -0.008 & 0.050 & 0.052 \\
\hline & $(0.005)$ & $(-0.192)$ & $(1.429)$ & $(1.477)$ \\
\hline \multirow[t]{2}{*}{ Marriage } & -0.092 & -0.098 & 0.022 & 0.013 \\
\hline & $(-0.740)$ & $(-0.791)$ & $(0.211)$ & $(0.125)$ \\
\hline \multirow[t]{2}{*}{ Experience } & -0.006 & -0.009 & $-0.092^{\star \star}$ & $-0.096^{\star \star}$ \\
\hline & $(-0.155)$ & $(-0.230)$ & $(-2.766)$ & $(-2.902)$ \\
\hline \multirow[t]{2}{*}{ Firm Age } & -0.002 & -0.001 & $0.050^{*}$ & $0.048^{*}$ \\
\hline & $(-0.058)$ & $(-0.031)$ & $(2.150)$ & (2.063) \\
\hline \multirow[t]{2}{*}{ Firm size } & $0.088^{\star}$ & $0.097^{\star \star}$ & -0.015 & -0.006 \\
\hline & $(-2.521)$ & $(2.757)$ & $(-0.531)$ & $(-0.214)$ \\
\hline \multirow[t]{2}{*}{ Ind1 } & -0.038 & -0.065 & -0.073 & -0.063 \\
\hline & $(-0.424)$ & $(-0.722)$ & $(-0.992)$ & $(-0.867)$ \\
\hline \multirow[t]{2}{*}{ Ind2 } & 0.046 & 0.029 & $-0.133^{t}$ & $-0.125^{\dagger}$ \\
\hline & $(0.526)$ & $(0.337)$ & $(-1.839)$ & $(-1.739)$ \\
\hline \multirow[t]{2}{*}{ Ind3 } & 0.010 & -0.016 & $-0.224^{\star \star}$ & $-0.204^{\star}$ \\
\hline & $(0.102)$ & $(-0.157)$ & $(-2.674)$ & $(-2.450)$ \\
\hline \multirow[t]{2}{*}{ COVID-19 } & $0.003^{\star \star \star}$ & $0.003^{\star \star \star}$ & $-0.002^{\star \star \star}$ & $-0.002^{\star \star \star}$ \\
\hline & $(9.269)$ & $(-9.445)$ & $(-5.920)$ & $(-5.343)$ \\
\hline \multirow[t]{2}{*}{ Firm performance } & 0.103 & 0.110 & & \\
\hline & $(0.676)$ & $(0.732)$ & & \\
\hline \multirow[t]{2}{*}{ COVID-19 * firm performance } & & $0.003^{\star}$ & & \\
\hline & & (2.043) & & \\
\hline \multirow[t]{2}{*}{ Employee growth rate } & & & $0.378^{*}$ & $0.479^{*}$ \\
\hline & & & $(2.078)$ & $(2.610)$ \\
\hline \multicolumn{3}{|c|}{ COVID-19 * employee growth rate } & & $-0.005^{\star \star}$ \\
\hline & & & & $(-2.777)$ \\
\hline \multirow[t]{2}{*}{ Constant } & $1.346^{\star \star}$ & $1.338^{\star \star}$ & $4.226^{\star \star \star}$ & $4.108^{\star \star \star}$ \\
\hline & (2.926) & $(-2.925)$ & $(11.030)$ & (10.779) \\
\hline $\mathrm{R} 2$ & 0.309 & 0.319 & 0.240 & 0.259 \\
\hline F-Statistic & $10.824^{\star \star \star}$ & $10.422^{\star \star \star}$ & $7.613^{\star \star \star}$ & $7.783^{\star \star \star}$ \\
\hline
\end{tabular}

$N=303 .{ }^{\dagger} p<0.1,{ }^{*} p<0.05,{ }^{* *} p<0.01,{ }^{* \star *} p<0.001$.

the participates about the growth in the number of employees of the current companies. The results in Model 6 show that COVID-19 has a significant negative effect on PWB $(b=-0.002$, $p=0.000)$. Thus, hypothesis 1 is supported. The results in Model 7 show that the interaction between COVID-19 and firm performance growth has a significant effect on PWB $(\mathrm{b}=$ $-0.005, p=0.006)$. Thus, hypothesis 2 is supported. The results are robust.

These results show that the research model is robust.

\section{CONCLUSIONS AND DISCUSSIONS}

\section{Conclusions}

According to the results of empirical analysis, this paper finds that the pandemic will significantly decrease the PWB of entrepreneurs. Firm performance will moderate the relationship between the pandemic and the entrepreneur's PWB. Specifically, the better the performance of firm, the greater the negative impact of the pandemic on entrepreneurs' PWB.

\section{Theorical Contributions}

First, this paper explores the influence of the pandemic on entrepreneurs' PWB. Although many scholars have studied the impact of the pandemic on individual well-being in different occupational types (e.g., female health professionals; Shahbaz et al., 2021), few scholars have paid attention to the relationship between the pandemic and entrepreneurs' wellbeing. The pandemic has had an important impact on enterprises, especially on SMEs (Andries et al., 2020; Nummela et al., 2020; Shepherd, 2020). The dual roles of entrepreneurs made them more vulnerable during the pandemic, which will significantly influence their PWB. Based on this logic, this paper explores the impact of the pandemic on entrepreneurs' PWB and fills the gap in the research about the COVID-19 pandemic and entrepreneurs' well-being.

Second, this paper establishes a research framework about the influence of enterprise characteristics on the relationship between pandemic and entrepreneurs' well-being, which has certain theoretical contributions. Previous studies have only addressed some of the factors affecting entrepreneurs' PWB (Stephan, 2018), and have not addressed context variables. The influence of external factors on the entrepreneur's wellbeing changes in different contexts (Moos, 1984; Hobfoll, 2001). This paper considers the entrepreneur's startup as the most important organizational context and analyze how pandemic affects the entrepreneur PWB differently in different contexts. This paper changes the previous well-being research model from the perspective of the dynamic interaction of environment, SMEs performance, and the entrepreneurs' $\mathrm{PWB}$. This perspective has certain theoretical contributions.

Finally, this paper enriches the boundary of COR theory. Based on COR theory, this paper explains the impact of SMEs' resource gain and loss on entrepreneurs' own PWB in the face of the pandemic. Due to the specificity of entrepreneurial activities, entrepreneurs focus on the resources at both individual level and firm level. Entrepreneurship is continuous process of resource acquisition, utilization and exploitation (Corbett, 2005; Busenitz and Arthurs, 2007), which this relies heavily on the entrepreneur's own ability to recognize, develop and manage resources (Hindle, 2011; Moroz and Hindle, 2012). These characteristics of entrepreneurial activity make the loss of resources in the start-ups affect the wellbeing of the entrepreneur. This study makes a theoretical contribution by extending the scope of resources in COR theory and enriching the application context of the theory.

\section{Practical Contributions}

First, this paper can help entrepreneurs maintain wellbeing in the pandemic and post-pandemic eras. The continuous and repeated outbreak of the pandemic will not only directly affect the personal health and well-being of entrepreneurs but will cause firm resource loss and will increase the difficulty of new resource 
acquisition. The conclusion of this paper provides a theoretical basis for entrepreneurs to better understand resource loss and resource shortage during the pandemic, which will help them maintain PWB.

Second, this paper can help entrepreneurs better understand the relationship between enterprise characteristics and their own well-being. According to the empirical conclusion of this paper, firm performance will affect the PWB of entrepreneurs. To maintain their PWB, entrepreneurs should selectively control the development speed of their enterprises when dealing with different environmental context. For example, when predicting the lack or shortage of resources in the future environment, entrepreneurs should slow down the growth of firms to obtain better PWB.

Finally, this paper provides a certain reference for local governments to adopt relevant policies. According to the conclusion, the pandemic will significantly reduce entrepreneurs' $\mathrm{PWB}$, and the negative impact is greater when the firm performance is better. Local governments should focus on helping companies with better performance in the past when formulating related support policies. These kinds of policies can decrease the impact of the pandemic on entrepreneurs' PWB.

\section{Limitations and Prospects}

This article mainly uses samples of entrepreneurs and entrepreneurial companies in Shandong Province, China. Future research should add samples from different nations to

\section{REFERENCES}

Adomako, S. (2021). Resource-induced coping heuristics and entrepreneurial orientation in dynamic environments. J. Bus. Res. 122, 477-487. doi: 10.1016/j.jbusres.2020.09.026

Alvarez, S. A., and Busenitz, L. W. (2007). The entrepreneurship of resource-based theory. J. Manag. 27, 755-775. doi: 10.1177/014920630102700609

Andries, P., Debackere, K., and Van Looy, B. (2020). Simultaneous experimentation as a learning strategy: Business model development under uncertainty-Relevance in times of COVID-19 and beyond. Strateg. Entrep. J.14, 556-559. doi: 10.1002/sej.1380

Backer, B. D., De Wachter, H., and Iania, L. (2021). Macrofinancial information on the post-COVID-19 economic recovery: Will it be V, U or L-Shaped? Finance Res. Lett. 21:101978. doi: 10.1016/j.frl.2021.101978

Baron, R. A. (2008). The role of affect in the entrepreneurial process. Acad. Manage. Rev. 33, 328-340. doi: 10.5465/amr.2008.31193166

Beleska-Spasova, E., Glaister, K. W., and Stride, C. (2012). Resource determinants of strategy and performance: the case of British exporters. J. World Bus. 47, 635-647. doi: 10.1016/j.jwb.2011.09.001

Bharadwaj, A. S. (2000). A resource-based perspective on information technology capability and firm performance: an empirical investigation. MIS Q. 24, 169-196. doi: 10.2307/3250983

Björklund, T. A., Mikkonen, M., Mattila, P., and van der Marel, F. (2020). Expanding entrepreneurial solution spaces in times of crisis: Business model experimentation amongst packaged food and beverage ventures. J. Bus. Ventur. Insights. 14:e00197. doi: 10.1016/j.jbvi.2020.e00197

Bonanno, G. A., Galea, S., Bucciarelli, A., and Vlahov, D. (2007). What predicts psychological resilience after disaster? the role of demographics, resources, and life stress. J. Consult. Clin. Psych. 75, 671-682. doi: 10.1037/0022-006X.75.5.671

Brieger, S. A., De Clercq, D., and Meynhardt, T. (2021). Doing good, feeling good? entrepreneurs' social value creation beliefs and work-related well-being. J. Bus. Ethics. 172, 707-725. doi: 10.1007/s10551-020-04512-6 test whether the research conclusions can be extended to other countries. Second, this paper primarily used questionnaire survey methods to verify the research questions. In the future, we can use interviews and other qualitative research methods to explore the impact mechanism of the pandemic on entrepreneurs' PWB. Finally, there are many ways to measure wellbeing. In the future, research on the impact of the pandemic on entrepreneurs' other types of well-being can be constructed.

\section{DATA AVAILABILITY STATEMENT}

The raw data supporting the conclusions of this article will be made available by the authors, without undue reservation.

\section{AUTHOR CONTRIBUTIONS}

ZX made the theoretical design of this article, reviewed, and revised the manuscript. HJ made the data analysis and drafted the manuscript. Both authors contributed to the article and approved the submitted version.

\section{FUNDING}

This work was supported by Startup Fund Project of Beijing Technology and Business University.

Brown, G. W., and Andrews, B. (1986). "Social support and depression," in Dynamics of Stress. The Plenum Series on Stress and Coping, eds M. H. Appley, and R. Trumbull (Boston, MA Springer), 257-282.

Brown, R., and Rocha, A. (2020). Entrepreneurial uncertainty during the Covid19 crisis: mapping the temporal dynamics of entrepreneurial finance. J. Bus. Ventur. Insights. 14:e00174. doi: 10.1016/j.jbvi.2020.e00174

Busenitz, L. W., and Arthurs, J. D. (2007). "Cognition and capabilities in entrepreneurial ventures," in The Psychology of Entrepreneurship, eds J. R. Baum, M. Frese, and R. A. Baron (Mahwah, NJ: Erlbaum), 131-150.

Butterick, M., and Charlwood, A. (2021). HRM and the COVID-19 pandemic: how can we stop making a bad situation worse? Hum. Resour. Manag. J. 31, 847-856. doi: 10.1111/1748-8583.12344

Chao, L. W., Pauly, M., Szrek, H., Pereira, N. S., and Gow, J. (2007). Poor health kills small business: illness and microenterprises in South Africa. Health Aff. 26, 474-482. doi: 10.1377/hlthaff.26.2.474

Chin, M. K., Zhang, S., Jahanshahi, A. A., and Nadkarni, S. (2021). Unpacking political ideology: CEO social and economic ideologies, strategic decisionmaking processes, and corporate entrepreneurship. Acad. Manag. J. 19:1228. doi: 10.5465/amj.2019.1228

Chittenden, F., Hall, G., and Hutchinson, P. (1996). Small firm growth, access to capital markets and financial structure: Review of issues and an empirical investigation. Small Bus. Econ. 8, 59-67. doi: 10.1007/BF00391976

Choi, Y. R., Ha, S., and Kim, Y. (2021). Innovation ambidexterity, resource configuration and firm growth: is smallness a liability or an asset? Small Bus. Econ. 21:3. doi: 10.1007/s11187-021-00507-3

Corbett, A. C. (2005). Experiential learning within the process of opportunity identification and exploitation. Entrep. Theory Pract. 29, 473-491. doi: 10.1111/j.1540-6520.2005.00094.x

Elgin, C., Yalaman, A., Yasar, S., and Basbug, G. (2021). Economic policy responses to the COVID-19 pandemic: the role of central bank independence. Econ. Lett. 204:109874. doi: 10.1016/j.econlet.2021.1 09874 
Fairlie, R., and Fossen, F. M. (2021). The early impacts of the COVID-19 pandemic on business sales. Small Bus. Econ. 21:4. doi: 10.1007/s11187-021-00479-4

Gielnik, M. M., Zacher, H., and Frese, M. (2012). Focus on opportunities as a mediator of the relationship between business owners' age and venture growth. J. Bus. Ventur. 27, 127-142. doi: 10.1016/j.jbusvent.2010.05.002

Goldberg, D. P., and Hillier, V. F. (1979). A scaled version of the General Health Questionnaire. Psychol. Med. 9, 139-145. doi: 10.1017/S0033291700021644

Hadad, Y., Keren, B., and Laslo, Z. (2013). A decision-making support system module for project manager selection according to past performance. Int. J. Proj. Manag. 31, 532-541. doi: 10.1016/j.ijproman.2012.10.004

Hahn, D. (2020). The psychological well-being of student entrepreneurs: a social identity perspective. Int. Entrep. Manag. J. 16, 467-499. doi: 10.1007/s11365-019-00607-3

Halbesleben, J., Neveu, J. P., Paustian-Underdahl, S. C., and Westman, M. (2014). Getting to the "COR": Understanding the role of resources in conservation of resources theory. J. Manag. 40, 1334-1364. doi: 10.1177/0149206314527130

Han, M. F. Y., Mahendran, R., and Yu, J. (2021). Associations between fear of COVID-19, affective symptoms and risk perception among communitydwelling older adults during a COVID-19 lockdown. Front. Psychol. 12:638831. doi: $10.3389 /$ fpsyg.2021.638831

Hindle, K. (2011). "The harmonized model of entrepreneurial process: 32 into one will go," in Regional Frontiers of Entrepreneurship Research: 8th International Australian Graduate School of Entrepreneurship (AGSE) Research Exchange, Swinburne University of Technology (Melbourne, ML), 41-52.

Hitt, M. A., Bierman, L., and Shimizu, K. (2001). Direct and moderating effects of human capital on strategy and performance in professional service firms: A resource-based perspective. Acad. Manage. J. 44, 13-28. doi: 10.5465/3069334

Hobfoll, S. E. (1989). Conservation of resources. a new attempt at conceptualizing stress. Am. Psychol. 44, 513-524. doi: 10.1037/0003-066X.44.3.513

Hobfoll, S. E. (2001). The influence of culture, community, and the nested-self in the stress process: advancing conservation of resources theory. Appl. Psychol: Int. Rev. 50, 337-421. doi: 10.1111/1464-0597.00062

Hobfoll, S. E. (2011). Conservation of resource caravans and engaged settings. $J$ Occup Organ Psych 84, 116-122. doi: 10.1111/j.2044-8325.2010.02016.x

Holland, D. V., and Shepherd, D. A. (2013). Deciding to persist: adversity, values, and entrepreneurs' decision policies. Entrep. Theory Pract. 37, 331-358. doi: $10.1111 / j .1540-6520.2011 .00468 . x$

Khan, A. H., Sultana, M. S., Hossain, S., Hasan, M. T., Ahmed, H. U., and Sikder, M. T. (2020). The impact of COVID-19 pandemic on mental health and wellbeing among home-quarantined Bangladeshi students: a cross-sectional pilot study. J. Affect. Disord. 277, 121-128. doi: 10.1016/j.jad.2020.07.135

Kinnunen, U., Feldt, T., Siltaloppi, M., and Sonnentag, S. (2011). Job demands-resources model in the context of recovery: testing recovery experiences as mediators. Eur. J. Work. Organ. Psychol. 20, 805-832. doi: 10.1080/1359432X.2010.524411

Kuckertz, A., Brändle, L., Gaudig, A., Hinderer, S., Reyes, C. A. M., Prochotta, A., et al. (2020). Startups in times of crisis-A rapid response to the COVID-19 pandemic. J. Bus. Ventur. Insights. 13, e00169. doi: 10.1016/j.jbvi.2020.e00169

Kumar, P., Kumar, N., Aggarwal, P., and Yeap, J. (2021). Working in lockdown: The relationship between COVID-19 induced work stressors, job performance, distress, and life satisfaction. Curr. Psychol. 21, 1-16. doi: 10.1007/s12144-021-01567-0

Lages, L. F., Jap, S. D., and Griffith, D. A. (2008). The role of past performance in export ventures: a short-term reactive approach. J. Int. Bus. Stud. 39, 304-325. doi: $10.1057 /$ palgrave.jibs.8400339

Lages, L. F., Mata, J., and Griffith, D. A. (2013). Change in international market strategy as a reaction to performance decline. J. Bus. Res. 66, 2600-2611. doi: $10.1016 /$ j.jbusres.2012.05.018

Lanivich, S. E. (2015). The RICH entrepreneur: Using conservation of resources theory in contexts of uncertainty. Entrep. Theory Pract. 39, 863-894. doi: $10.1111 /$ etap. 12082

Leamy, M., Bird, V., Le Boutillier, C., Williams, J., and Slade, M. (2011). Conceptual framework for personal recovery in mental health: systematic review and narrative synthesis. Br. J. Psychiatry. 199, 445-452. doi: 10.1192/bjp.bp.110.083733

Leung, Y. K., Mukerjee, J., and Thurik, R. (2020). The role of family support in work-family balance and subjective well-being of SME owners. J. Small Bus. Manag. 58, 130-163. doi: 10.1080/00472778.2019. 1659675

Li, J., Zhang, Y., and Niu, X. (2021). The COVID-19 pandemic reduces trust behavior. Econ. Lett. 199, 109700. doi: 10.1016/j.econlet.2020.109700

Mache, S., Servaty, R., and Harth, V. (2020). Flexible work arrangements in open workspaces and relations to occupational stress, need for recovery and psychological detachment from work. J. Occup. Med. Toxicol. 15, 1-11. doi: 10.1186/s12995-020-00258-z

Marshall, D. R., Meek, W. R., Swab, R. G., and Markin, E. (2020). Access to resources and entrepreneurial well-being: a self-efficacy approach. J. Bus. Res. 120, 203-212. doi: 10.1016/j.jbusres.2020.08.015

Mishra, C. S., and Zachary, R. K. (2013). The nature of the firm, the growth and resource-based theories of the firm, and the emergent theory of the entrepreneur: a dedication to Nobel Laureate Ronald Coase. Entrep. Res. J. 3, 433-436. doi: 10.1515/erj-2013-0067

Moos, R. H. (1984). Context and coping: toward a unifying conceptual framework. Am J Commun Psychol 12, 5-36. doi: 10.1007/BF00896933

Moroz, P. W., and Hindle, K. (2012). Entrepreneurship as a process: Toward harmonizing multiple perspectives. Entrep. Theory Pract. 36, 781-818. doi: 10.1111/j.1540-6520.2011.00452.x

Nummela, N., Paavilainen-Mäntymäki, E., Harikkala-Laihinen, R., and Raitis, J. (2020). When all doors close: implications of COVID-19 for cosmopolitan entrepreneurs. Int. Small Bus. J. 38, 711-717. doi: 10.1177/0266242620954127

OECD (2020). Coronavirus (COVID-19): SME Policy Responses. Available online at: https://www.oecd.org/coronavirus/policy-responses/coronaviruscovid-19-sme-policy-responses-04440101/

Patel, P. C., and Rietveld, C. A. (2020). The impact of financial insecurity on the self-employed's short-term psychological distress: Evidence from the COVID19 pandemic. J. Bus. Ventur. Insights. 14:e00206. doi: 10.1016/j.jbvi.2020.e00206

Peng, L. (2020). Small and medium-sized enterprises under the COVID19 pandemic: Operate the business till the sunrise even if you cannot fall asleep today. Available online at: https://www.163.com/tech/article/ F62SBS3C000999D8.html

Phillips, B. D., and Kirchhoff, P. (1989). Formation, growth and survival; small firm dynamics in the U.S. economy. Small Bus. Econ. 1, 65-74. doi: 10.1007/BF00389917

Powers, J. B., and McDougall, P. P. (2005). University start-up formation and technology licensing with firms that go public: A resource-based view of academic entrepreneurship. J. Bus. Ventur. 20, 291-311. doi: $10.1016 /$ j.jbusvent.2003.12.008

Quas, A., Mart,í, J., and Reverte, C. (2021). What money cannot buy: a new approach to measure venture capital ability to add non-financial resources. Small Bus. Econ. 57, 1361-1382. doi: 10.1007/s11187-020-0 0352-w

Rauch, A., and Hatak, I. (2016). A meta-analysis of different HR-enhancing practices and performance of small and medium sized firms. J. Bus. Ventur. 31, 485-504. doi: 10.1016/j.jbusvent.2016.05.005

Ripp, J., Peccoralo, L., and Charney, D. (2020). Attending to the emotional well-being of the health care workforce in a new york city health system during the COVID-19 pandemic. Acad. Med. 95, 1136-1139. doi: 10.1097/ACM.0000000000003414

Shahbaz, S., Ashraf, M. Z., Zakar, R., and Fischer, F. (2021). Psychosocial, emotional and professional challenges faced by female healthcare professionals during the COVID-19 outbreak in Lahore, Pakistan: a qualitative study. BMC Women's Health. 21:197. doi: 10.1186/s12905-021-01344-y

Shamim, K., Ahmad, S., and Alam, M. A. (2021). COVID-19 health safety practices: Influence on grocery shopping behavior. J. Public Aff. 21:e2624. doi: $10.1002 /$ pa.2624

Shepherd, D. A. (2020). COVID 19 and Entrepreneurship: Time to Pivot? J. Manag. Stud. 57, 1750-1753. doi: 10.1111/joms.12633

Smith, K. G., Gannon, M. J., Grimm, C., and Mitchell, T. R. (1988). Decision making behavior in smaller entrepreneurial and larger professionally managed firms. J. Bus. Ventur. 3, 223-232. doi: 10.1016/0883-9026(88)90016-X

Sonnentag, S., Kuttler, I., and Fritz, C. (2010). Job stressors, emotional exhaustion, and need for recovery: A multi-source study on the benefits of psychological detachment. J. Vocat. Behav. 76, 355-365. doi: 10.1016/j.jvb.2009. 06.005 
Sonnentag, S., and Zijlstra, F. (2006). Job characteristics and off-job activities as predictors of need for recovery, well-being, and fatigue. J. Appl. Psychol. 91, 330-350. doi: 10.1037/0021-9010.91.2.330

Spiegel, M., and Tookes, H. (2021). Business restrictions and COVID-19 fatalities. Rev. Financ. Stud. 34, 5266-5308. doi: 10.1093/rfs/hhab069

Stam, W., Arzlanian, S., and Elfring, T. (2014). Social capital of entrepreneurs and small firm performance: A meta-analysis of contextual and methodological moderators. J. Bus. Ventur. 29, 152-173. doi: 10.1016/j.jbusvent.2013.01.002

Stephan, U. (2018). Entrepreneurs' mental health and well-being: A review and research agenda. Acad. Manag. Perspect. 32, 290-322. doi: 10.5465/amp.2017.0001

Tang, J., Zhang, S. X., and Lin, S. (2021). To reopen or not to reopen? How entrepreneurial alertness influences small business reopening after the COVID19 lockdown. J. Bus. Ventur. Insights. 16:e00275. doi: 10.1016/j.jbvi.2021.e00275

Thorgren, S., and Williams, T. A. (2020). Staying alive during an unfolding crisis: How SMEs ward off impending disaster. J. Bus. Ventur. Insights. 14:e00187. doi: 10.1016/j.jbvi.2020.e00187

Tian, X., Kou, G., and Zhang, W. (2020). Geographic distance, venture capital and technological performance: evidence from Chinese enterprises. Technol. Forecast. Soc. Change. 158:120155. doi: 10.1016/j.techfore.2020.120155

Uy, M. A., Foo, M. D., and Song, Z. (2013). Joint effects of prior start-up experience and coping strategies on entrepreneurs' psychological well-being. J. Bus. Ventur. 28, 583-597. doi: 10.1016/j.jbusvent.2012.04.003

Uy, M. A., Sun, S., and Foo, M. D. (2017). Affect spin, entrepreneurs' well-being, and venture goal progress: The moderating role of goal orientation. J. Bus. Ventur. 32, 443-460. doi: 10.1016/j.jbusvent.2016.12.001

Veldhoven, V. M., and Broersen, S. (2003). Measurement quality and validity of the "need for recovery scale". Occup. Environ. Med. 60:i3-i9. doi: 10.1136/oem.60.suppl_1.i3

Verbeke, A., and Yuan, W. (2021). A few implications of the covid-19 pandemic for international business strategy research. J. Manag. Stud. 58, 597-601. doi: 10.1111/joms. 12665

Walmsley, T. L., Rose, A., and Wei, D. (2020). Impacts on the U.S. macroeconomy of mandatory business closures in response to the COVID-19 pandemic. Appl. Econ. Lett. 28, 1293-1300. doi: 10.1080/13504851.2020.1809626

Wang, B., Liu, Y., Qian, J., and Parker, S. K. (2021). Achieving effective remote working during the COVID-19 pandemic: A work design perspective. Appl. Psychol. 70, 16-59. doi: 10.1111/apps.12290

Wang, X. (2020). Financing difficulties during the COVID-19: Insist and survive. Available online at: https://36kr.com/p/1725088727041
Williams, T. A., and Shepherd, D. A. (2016). Victim entrepreneurs doing well by doing good: Venture creation and well-being in the aftermath of a resource shock. J. Bus. Ventur. 31:365-387. doi: 10.1016/j.jbusvent.2016.04.002

Wolfe, M. T., and Patel, P. C. (2021). Everybody hurts: Self-employment, financial concerns, mental distress, and well-being during COVID-19. J. Bus. Ventur. Insights. 15, e00231. doi: 10.1016/j.jbvi.2021.e00231

World Bank (2020). The Global Economic Outlook During the COVID-19 Pandemic: A Changed World. Available online at: https://www.worldbank. org/en/news/feature/2020/06/08/the-global-economic-outlook-during-thecovid-19-pandemic-a-changed-world

Yarovaya, L., Mirza, N., Abaidi, J., and Hasnaoui, A. (2021). Human capital efficiency and equity funds' performance during the COVID-19 pandemic. Int. Rev. Econ. Finance. 71, 584-591. doi: 10.1016/j.iref.2020. 09.017

Yu, X., Meng, X., Cao, G., and Jia, Y. (2020). Exploring the relationship between entrepreneurial failure and conflict between work and family from the conservation of resources perspective. Int. J. Confl. Manag. 31, 417-440. doi: 10.1108/IJCMA-09-2019-0157

Zhao, H., Seibert, S. E., and Lumpkin, G. T. (2010). The relationship of personality to entrepreneurial intentions and performance: a metaanalytic review. J. Manag. 36, 381-404. doi: 10.1177/01492063093 35187

Conflict of Interest: The authors declare that the research was conducted in the absence of any commercial or financial relationships that could be construed as a potential conflict of interest.

Publisher's Note: All claims expressed in this article are solely those of the authors and do not necessarily represent those of their affiliated organizations, or those of the publisher, the editors and the reviewers. Any product that may be evaluated in this article, or claim that may be made by its manufacturer, is not guaranteed or endorsed by the publisher.

Copyright (C) $2022 \mathrm{Xu}$ and Jia. This is an open-access article distributed under the terms of the Creative Commons Attribution License (CC BY). The use, distribution or reproduction in other forums is permitted, provided the original author(s) and the copyright owner(s) are credited and that the original publication in this journal is cited, in accordance with accepted academic practice. No use, distribution or reproduction is permitted which does not comply with these terms. 